\title{
Aplicación de la propuesta de investigación en el contexto de la educación a distancia del futuro profesor de lengua y literatura
}

\section{Application of research proposal in the context of distance learning of the future language and literature teacher}

\author{
Vitalii P. Matsko ${ }^{1}$, Svitlana Y. Piroshenko ${ }^{21}$, Valentina I. Sliuzko ${ }^{3}$, \\ Valentyna A. Filiniuk ${ }^{4}$, Halyna O. Tsyts ${ }^{5}$ \\ Khmelnytskyi Humanitarian-Pedagogical Academy, Ukraine ${ }^{1,2,3,4,5}$ \\ iD ORCID ID: https://orcid.org/0000-0001-5512-3743 1 \\ ORCID ID: https://orcid.org/0000-0002-5818-1735² \\ ORCID ID: https://orcid.org/0000-0003-2123-217X 3 \\ ORCID ID: https://orcid.org/0000-0003-4951-7732 \\ ORCID ID: https://orcid.org/0000-0001-7006-2555
}

Recibido: 15 de junio de 2021

Aceptado: 01 de octubre de 2021

\section{Resumen}

El objetivo de esta investigación es estudiar el potencial de aplicación de la propuesta de investigación en el contexto del aprendizaje a distancia de los futuros profesores de lengua y literatura. El método de investigación se basa en una evaluación sumativa (cuestionario cerrado del autor, prueba a través de la técnica de L. Yovaysha modificada por H. V. Rezapkina) y experimento formativo, análisis de texto, entrevista en profundidad, métodos matemáticos y estadísticos de procesamiento de datos, representación visualizada y análisis de generalización funcional de los datos empíricos obtenidos. Al comparar los resultados de la evaluación sumativa y el experimento formativo se encontró que el nivel de RPCQ es positivo en todos los encuestados. La tasa de crecimiento mínima de RPCQ fue 3.3\% y la máxima de $16.6 \%$. La diferencia entre los límites superior e inferior fue del 13,3\%. También se observó que hay fluctuaciones significativas en las tasas de crecimiento de RPCQ incluso dentro de un subgrupo de la tasa de éxito académico. En cuanto a los niveles de avance de RPCQ, el avance de RPCQ se centró en Nivel Satisfactorio en el 52,9\% de los casos. Por tanto, se considera necesario investigar los factores que influyen en la mejora de RPCQ en un futuro próximo, y si RPCQ depende de la especialidad de los estudiantes.

Palabras clave: propuesta de investigación, competencia investigadora, sociedad del conocimiento, IES, redacción académica, filología, educación.

\footnotetext{
Abstract

${ }^{1}$ Correspondencia al autor

E-mail: svitlanarom70@gmail.com
}

The objective of this research is to study the potential of application of the research proposal in the context of distance learning of future teachers of language and literature. The research 
method is based on a summative evaluation (closed questionnaire of the author, test through the technique of L. Yovaysha modified by H. V. Rezapkina) and formative experiment, text analysis, in-depth interview, mathematical and statistical methods of processing of data, visualized representation and functional generalization analysis of the empirical data obtained. When comparing the results of the summative evaluation and the formative experiment, it was found that the level of RPCQ is positive in all respondents. RPCQ's minimum growth rate was $3.3 \%$ and the maximum was $16.6 \%$. The difference between the upper and lower limits was $13.3 \%$. It was also observed that there are significant fluctuations in RPCQ growth rates even within a subgroup of the academic success rate. Regarding RPCQ levels of progress, RPCQ progress was centered on Satisfactory Level in $52.9 \%$ of the cases. Therefore, it is considered necessary to investigate the factors that influence the improvement of RPCQ in the near future, and if RPCQ depends on the specialty of the students.

Keywords: research proposal, research competence, knowledge society, HEIs, academic writing, philology, education

\section{Introduction}

Diverging from the ideas of scholastic didactics and the advent of the era of modernity, the task of higher education has always been not only the retransmission of ready-made knowledge, but also the creation of such an educational environment that would stimulate research initiative. This is in line with the desire to achieve the principles of knowledge-based society (ESG, 2015), which means the type of society that is necessary to ensure competitiveness, as well as individual and collective success in the ever-changing economic and political situation. The foundation of knowledge-based society is well-educated citizens, and such a society is driven by the mechanism of innovation, entrepreneurship initiated by the active community (Djoub, 2017). Knowledge-based society provides the generation, exchange and application of knowledge as a product of human intelligence (Rahman, 2019). In fact, it relies on the knowledge of citizens as a driver of innovation and a guarantor of general wellbeing (Grbić et al., 2020).

Knowledge-based society as a trend and goal is reflected in international and national doctrines on the functioning and forecasts for the development of higher education. In particular, the Standards and Guidelines for Quality Assurance in the European Higher Education Area state that "Higher education, research and innovation play a crucial role in supporting social cohesion, economic growth and global competitiveness" (ESG, 2015, p. 5). The same applies to the discourse on control mechanisms in HEIs: "Quality assurance policies are most effective when they reflect the relationship between research and learning \& teaching" (ESG, 2015, p. 7). 
The dominance of the research aspect in the field of education is pervasive, even for those areas that do not directly affect the functioning of the economy and technical progress. In particular, this study will address the niche of philology. Philology is most closely related to communication, which is crucial in the field of business relations. However, the very position of philology in the modern world is currently under threat, because the core problem of philology today, as I see it, is whether it will survive at all (Pollock, 2009). This is despite the fundamental nature of philology as a science, which some researchers equate to evolutionary biology in terms of the importance in the mechanism of progressive development of mankind (O’Hara, 1996). Evolutionarily, philology has been an integral exponent or even a source of critical thinking (Pollock, 2009).

Let us briefly note that in the context of this research we consider philology as a complex subject that covers linguistics and literary studies, which is the basis of professional training out of students majoring specialty 035 Philology in modern HEIs. In the information age, the applied philological subjects such as communicative linguistics, linguistic pragmatics, business language, etc. are especially important. Besides, both language and literature are the source and tool for instilling aesthetic taste and imagination (Duignan, 2021), which is lacking in technological humanity.

The Standard of Higher Education for the major 035 Philology states in the list of general competencies that one of the main is the ability to conduct research at the appropriate level (Ministry of Education and Science of Ukraine, 2019). The importance of skills of participation in theoretical and/or applied research in the field of philology is also noted. The matrix of conformity of the learning outcomes and competencies defined by the Standard clearly states that the student with a bachelor's degree must have the skills to participate in theoretical and/or applied research in the field of philology (Ministry of Education and Science of Ukraine, 2019). In addition, research activities in modern HEIs of Ukraine are carried out and encouraged by the current Laws "On Higher Education" (Verkhovna Rada of Ukraine, 2014), “On Education” (Verkhovna Rada of Ukraine, 2017), “On Scientific, Research and Technical Activity" (Verkhovna Rada of Ukraine, 2016), university charters.

The very content of philological majors provides a mandatory research component, which is enshrined at the level of regulatory documents and scholars in studies of the content and structure of competencies of modern philologist (Koval \& Masliuk, 2018). This is the socalled Research Competence, which is understood as the quality of the student's personality, the totality of his/her knowledge, values, needs and experience of research activities. They result in the willingness and ability to function fully within their profession. 
The strengthening of the emphasis on the research component of professional training entails the urgency of finding effective methods of organising the learning environment and generally ensuring the activities of HEIs in such a way as to implement the attitude to innovative content of higher education. This is possible only through the constant emphasis on research work of the university community: both teachers and students. It is this model that will ensure the permanent prerogative of research activities, relevant links to research and innovation (ESG, 2015; Jansen, 2020) in higher education. The purpose of the standards and recommendations of Quality Assurance Policies is to stimulate and develop HEIs that support active research (ESG, 2015).

An effective method of stimulating the research work of students, in particular students majoring in philology, is the method of research proposal, which is the subject of our study. The context of the application of the method is the distance learning environment, as forced quarantine measures related to the coronavirus pandemic were introduced at the time of the study. On the other hand, the development of modern education in the direction of blended learning (Medina, 2018; del Río, 2021) further urges the issue of effective ways to develop Research Competence, which is a necessary professional competence of modern students, not only during face-to-face interaction with students, but especially in the context of distance learning.

\section{Literature review}

Research proposal writing is considered to be a complex form of training applicants, as it requires experience (which applicants always lack) of consistent organisation, conduct and representation of scientific work. Discussion of the experiment in the work of (Saeed et al., 2020) through the method of research proposal writing for philologists allowed finding that the greatest difficulties were caused by the search for options and choice of research topic, selection of research methods, writing the first articles under the research, selection of relevant scientific literature on the topic. There were also difficulties in establishing cooperation with the supervisor in such a way that it took the form of stimulating consultative meetings and did not offset the student's active search (Saeed et al., 2020).

By its part, Pringle-Barnes and Cheng (2018) view the research proposal as a form of independent learning, as the formal application of a research proposal before entering graduate and postgraduate studies may involve only the most minimal supervisor's assistance. However, the use of research proposal in the context of regular bachelor's training also implies maximum student independence, involving an arsenal of previously acquired skills and knowledge to build 
a scaffolding system to overcome difficulties arising in the course of preparing a research proposal. According to the definition of the term of "active learning" in the work of Roman and Uttamchandani (2018), research proposal can also be considered as a kind of active learning. The distance learning paradigm is also based on the autonomous work of students. In our opinion, the research proposal method is particularly favourable in the context of distance learning.

The work of Augustsson and Jaldemark (2014), who explored the features of online supervision, is also relevant for our study. In the paradigm of distance learning and the application of research proposal for educational purposes, the method of interaction is very important in such a complex process for inexperienced students as writing a research proposal. The paper places more emphasis on how it is appropriate to organise communication on the part of teachers, in order, on the one hand, to ensure that students implement the research proposal, and on the other hand, to ensure maximum autonomy of their work.

The study by Saeed et al. (2020) identified problems in writing a research proposal that generally reflect students' weaknesses in research method learning. According to faculty and, in particular, members of university commissions who consider students entering further educational qualifications after the bachelor's degree, most students have difficulty understanding and meeting the needs of building a research proposal (Pardede, 2019). This testifies again in favour of the unwillingness of modern higher education to ensure the transformation of the human community into a knowledge-based society and the extremely insufficient provision of research competence in students or at least the inclinations to research activity in a very limited circle of students.

The features of writing a research proposal depend on the field of knowledge (Zondi, 2018; Pardede, 2019). Difficulties mostly arise because students presenting a research proposal need to develop a full step-by-step plan for future research, which is a difficult task for students who do not even know what a master's thesis, dissertation or other serious research is as they don't have practice. Despite the fact that in the previous stages of work students prepared and defended term papers and diploma projects, a research proposal was not required for them. Besides, previous research papers were only one-time projects, which are definitely not enough for students to gain competence in this niche. Instead, in the research proposal, the entire future project crystallises into a specific form that should be as attractive as possible to convince the commission or potential supervisor of the feasibility of the proposed research and the ability to do it in full (Suryatiningsih, 2019). It is important to formulate opinions as succinctly as possible in accordance with the ethics of scientific style (Maznun et al., 2017). 
According to Yusuf (2013), the most common problems that students face when writing a research proposal are the proportions of the sections: Introduction (46.6\%), Literature review (about 60\%) and Research methods (about 73.3\%). Kheryadi (2018) focuses on the analysis of problems related to students writing the introductory part of a research proposal. Kheryadi (2018) emphasises that it is necessary to clearly explain to students the need to present a research proposal in accordance with standard models of writing a research proposal, especially with regard to its structural elements and linguistic features of presentation (Appendix A). A number of works have a generalising and methodological nature as to writing a research proposal, focusing on mixed method research proposal (Wa Mungai, 2019), the dependence of research proposal as a preliminary form of work on the type of full-scale research represented at the teacher's discretion (Morris, 2020), structural content and performing various structural stages of the study (Opaleye \& Aiyedun, 2020), etc.

Analysis of sources on the topic showed that the common thread through all research studies on research proposal — whether as a method of educational activity or as a reporting and control form of scientific work during admission to master's or $\mathrm{PhD}$ level - is equally open and acute issue of lack of student training to write a research proposal and to conduct research work in general.

Given the problems identified during the literature review, the aim of this research is to study the potential application of research proposal of future language and literature teachers in terms of distance learning. This aim involves the consistent fulfilment of the following research objectives:

1) To justify the feasibility and application of research proposal at the theoretical and methodological level in order to develop the basics of research competence in future language and literature teachers in the paradigm of bachelor's degree (even in distance format in view of the forced quarantine restrictions).

2) To develop a model of research of readiness of students majoring in philology and pedagogy for conducting research, in particular writing a research proposal.

3) To present an experimental version of research proposal training and evaluate the effectiveness of training on the methodology of working with research proposal using the concept of research proposal confidence and quality (RPCQ), the representation of which in the structure of professional competencies of students we proposed to individually measure by the author's scheme.

4) To identify priority areas for further research on the implementation of research proposal during distance learning, in-class learning or blended learning. 


\section{Materials and methodology}

\section{Sampling}

This study was implemented within the extracurricular activity of third-year students of the Faculty of Primary Education and Philology as part of a special project to improve the learning outcomes for the subject Methods and Organisation of Research through the tactics of advanced placement courses. The subject is designed for undergraduate students, but it was decided to involve third-year students majoring in Secondary Education (Ukrainian Language and Literature) in the experiment in line with the experimental innovative trend of active involvement of undergraduate students in research. However, taking into account the fact that 1.5 years have passed from the stage of the summative assessment to the generalisation of the results of the formative experiment (January 2019 - May 2020), the respondents completed the research as students of the fourth year of bachelor's degree. Taking into account the capacity of the research procedure and the need for quality work in the direction of academic advising, 17 students of one academic group were involved in the study.

According to the rating of academic performance, respondents distributed as follows: excellent - 2 (respondents \#1-2); very good - 4 (respondents \#3-6); good - 6 (respondents \#712); satisfactory - 3 (respondents \#13-15); sufficient - 2 (respondents \#16-17). As mentioned above, the use of research proposal for educational purposes during basic university training, and not directly during admission to master's or postgraduate studies, is very limited, which we are trying to overcome by offering an extended use of research proposal in the preparation of future bachelors of philology. . Despite such a limited application of the research proposal (as a result of which the novelty of our study is more pronounced), the closest in structure to our proposed experiment is the work of Saeed et al. (2020). Within it, the study was based on the involvement of 10 postgraduates joining applied linguistics in a Malaysian university.

We take the position in this study that, in our opinion, elements of research activity should be implemented in the educational environment of not only those students who plan to continue their graduate and postgraduate studies, but also at the stage of obtaining a bachelor's degree in general.

\section{Research methods}

Special scientific methods were used during the preparation of the current study. In the framework of ascertaining experiment, author's closed-ended questionnaire, testing through the 
L. Yovaysha's technique modified by H. V. Rezapkina were used. In addition, the main data for results and conclusion section of the current paper were obtained through formative experiment. Besides, text analysis was applied in analysing the research proposal of respondents; in-depth interview was a useful technique when discussing the results of the study with its participants and teachers of the Department of Ukrainian Language, Ukrainian and Foreign Literature at the final conference. Mathematical and statistical methods of data processing allowed systemizing and visualization of the results. Visualised representation (construction of graphs, tables) and functional generalising analysis of the obtained empirical data were a proper way of a research work for preparing the conclusions.

\section{The stages of the experiment}

Prior to the beginning of the experimental part of the study, an anonymous survey was conducted through the author's closed-ended questionnaire (Appendix B) and anonymous testing through the L. Yovaysha's technique modified by Rezapkina, Professional Inclinations Questionnaire (Appendix C). This is in line with the recommendations of Saeed et al. (2020) on the need to use surveys and interviews before applying the research proposal method, as such a preliminary stage of the study will enrich our understanding of how these factors affect their writing of research proposals. The questionnaire was self-reflective and concerned students' assessment of factors that potentially contribute to the development of research competence, as well as their assessment of their own confidence in the implementation of certain stages of work on a research proposal. The testing through the Yovaysha's technique modified by Rezapkina - Professional Inclinations Questionnaire - was appropriate for our study, because it can determine the inclination to research (intellectual) work, scientific activity (students with such inclinations are characterised by rationality, independence of judgment, analytical mind).

At the initial stage, the level of students' RPCQ was determined by the sum of points obtained for the questionnaire (note that only the number of points focused on level II "Inclination to research (intellectual) work") - $\max 12$ points $\times 5$ (in order to bring it closer to the weight of the test score $)=\max 60$ points; and testing $-\max 100$ points. Thus, a maximum of 160 points could be obtained at the first stage, which would mean the highest level of RPCQ and, accordingly, the most favourable conditions for the development of research competence. The option of defining RPCQ was chosen, which meant even not that much competence in creating a research proposal, but a predisposition to conduct research, in particular through writing a research proposal, due to the fact that students were not familiar with the format and 
the essence of the research proposal before the experiment. Therefore, it couldn't be performed until the stage of special targeted training, which will be discussed below.

After a specially designed curriculum which was implemented in the training environment for preparation for scientific activities, namely to write a research proposal (stage of the formative experiment), students get the assignment during distance learning to determine the topic (previously agreed with supervisors) and develop their own research proposal, using an arsenal of previously acquired theoretical knowledge and practical skills. The time for preparing the research proposal coincided with a period of forced quarantine due to the coronavirus pandemic. In this regard, the work on research proposal projects was as independent as possible, and communication between students and their supervisors was distant. After completing the work on the research proposal, the commission of teachers of the Department of Ukrainian Language, Ukrainian and Foreign Literature and representatives of the administration of the HEI evaluated the submitted works and determined the results. The results were evaluated according to the following criteria (Table 1).

Table 1

Criteria for the evaluation of research proposal by members of the jury

\begin{tabular}{|c|c|c|c|}
\hline \multicolumn{2}{|c|}{ Positive Beneficial Area } & \multicolumn{2}{|c|}{ Unfavourable Negative Zone } \\
\hline Criterion & Points $(+)$ & Criterion & Points (-) \\
\hline $\begin{array}{l}\text { 1. Choosing the research area and } \\
\text { detecting the research problem. }\end{array}$ & +5 points $\max$ & 1. Failure to be concise. & -3 points $\max$ \\
\hline $\begin{array}{l}\text { 2. Formulating the title of the } \\
\text { research proposal. }\end{array}$ & +5 points $\max$ & $\begin{array}{l}\text { 2. Failure to cite landmark works } \\
\text { in literature review. }\end{array}$ & -3 points $\max$ \\
\hline 3. Abstract writing. & +5 points $\max$ & $\begin{array}{l}\text { 3. Failure to delimit the } \\
\text { contextual boundaries of } \\
\text { research. }\end{array}$ & -3 points $\max$ \\
\hline 4. Research context involving. & +5 points $\max$ & $\begin{array}{l}\text { 4. Failure to develop a coherent } \\
\text { and persuasive argument for the } \\
\text { proposed research. }\end{array}$ & -3 points max \\
\hline 5. Search of relevant references. & +5 points $\max$ & $\begin{array}{l}\text { 5. Sloppy or imprecise writing, } \\
\text { or poor grammar. }\end{array}$ & -3 points max \\
\hline 6. Literature review conducting. & +5 points $\max$ & $\begin{array}{l}\text { 6. Too much detail on minor } \\
\text { issues, but not enough detail on } \\
\text { major issues. }\end{array}$ & -3 points $\max$ \\
\hline 7. Research questions developing. & +5 points $\max$ & $\begin{array}{l}\text { 7. Too long or too short research } \\
\text { proposal. }\end{array}$ & -3 points $\max$ \\
\hline 8. Research methods selecting. & +5 points $\max$ & 8. Obsolete sources of literature. & -3 points $\max$ \\
\hline $\begin{array}{l}\text { 9. Extracting the significance of } \\
\text { research. }\end{array}$ & +5 points $\max$ & $\begin{array}{l}\text { 9. Failure to follow the logic of } \\
\text { scientific expression. }\end{array}$ & -3 points $\max$ \\
\hline 10. References arrangement. & +5 points $\max$ & 10. Plagiarizm* & -3 points $\max$ \\
\hline 11. Deadline compliance. & +5 points $\max$ & 11. Poorly defined novelty & -3 points $\max$ \\
\hline
\end{tabular}

Works with more than $10 \%$ of plagiarism would be nulled. 
First, the Positive Beneficial Area indicators were evaluated, from which, if necessary, the points for the Unfavourable Negative Zone were deducted. Therefore, the potential maximum score at this stage is 55 points. In general, the experimental model of the study had the following structure (Table 2).

Table 2

Application of research proposal under the conditions of distance learning

\begin{tabular}{|c|c|c|}
\hline \multicolumn{3}{|c|}{ Research proposal confidence and quality (RPCQ) } \\
\hline Summative assessment & \multicolumn{2}{|c|}{ Formative experiment } \\
\hline Stage I & Stage II & Stage III \\
\hline The initial stage & $\begin{array}{l}\text { Special training and education of } \\
\text { applicants for writing research } \\
\text { proposal }\end{array}$ & $\begin{array}{l}\text { Control, diagnostic and } \\
\text { generalising stage }\end{array}$ \\
\hline 1. Closed-ended survey. & 2.1. More detailed way of & 1. Evaluation by the jury. \\
\hline $\begin{array}{l}\text { Testing through the L. Yovaysha's } \\
\text { technigue modified by }\end{array}$ & $\begin{array}{l}\text { implementing these special } \\
\text { trainings would be described in the }\end{array}$ & 2. Collective discussion of the \\
\hline H.V. Rezapkina - Professional & Results paragraph. & Summing up. \\
\hline Inclinations Questionnaire & 2.2. Writing an individual research & \\
\hline 160 points max & proposal. & 160 points max \\
\hline
\end{tabular}

After starting the experiment, students were asked to prepare the preliminary model of the research proposal (usually written in five to six paragraphs, in two pages) during the first 1.5 months of study. After agreement with the supervisors, the assignment was to expand the preliminary research proposal to the scope of the standard model (2,000-3,000 words), which is typical for the master's level (Pardede, 2019).

\section{The method of generalising the results}

The purpose of these two stages of the study was to determine the level of RPCQ improvement individually for each respondent (not within the group, as individual progress was most important to us) and to distribute the participants of the experiment according to the levels of progress:

$1-5 \%$ - low progress;

(1) 6-10\% - satisfactory;

(2) $11-15 \%$ - good;

(3) 16-20\% - very good;

(4) $\geq 21$ - advanced.

In our opinion, this approach is the most demonstrative and correct, because it potentially allows to adequately assess the degree of RPCQ increase taking into account the 
growth of RPCQ even in students with extremely low and extremely high academic performance.

\section{Results}

\section{Preliminary preparation of students for writing a control research proposal}

Since it is advisable to present the results of the study in the comparison of the summative and formative stages, we consider it necessary to begin with a presentation of the pedagogical model aimed at stimulating research activities of students in general and skills in writing research proposals in particular. Thus, even before the introduction of quarantine restrictions, that is in the format of the direct in-class interaction, an annual preparatory work on the methodology of writing a research proposal was conducted with students-respondents. Before giving students the assignment of drawing up their research proposals, special theoretical and practical training sessions were conducted for them. On the one hand, they had a decisive influence on further work with individual research proposals, and on the other hand, they provided thorough knowledge of the methods of organising research activities in general.

The training consisted of in-class and extracurricular group and individual work (instructional lectures, meetings with prominent scholars, conversations, discussions, practical assignments with subsequent collective discussion, etc.) in the following areas, which are specific ways to use the generalised research proposal as a method if organisation of educational activities in HEIs:

1. Identification of current linguistic and literary problems that need a scientific solution.

2. Background of the topic area identification.

3. Statement of the problem with accordance with defined background.

4. Research objectives formulation.

5. Research Significance identification.

6. Research Scope marking.

7. Operational Plan within further the research work composing.

8. Literature Review Writing:

a. search and selection of relevant literature;

b. grouping of literature sources by areas of scientific attention to the research problem;

c. elimination of sources that are not relevant to the coverage of the topic;

d. construction of the historical perspective of the research question development;

e. highlighting the positions of other researchers:

(1) with whom we agree; 
(2) with whom we polemize;

(3) which we use and develop in own study;

(4) which we deny; building discourse accordingly

9. Study of typical methods of scientific knowledge used in philological research.

10. Features of the organization of theoretical and empirical research: data collection and generalization.

11. The specifics of building a step-by-step generalized and detailed plan of scientific research.

12. Communicating the results (possible ways to represent the results of the study).

13. Convincing Significance of Research part writing.

14. Timeline scheduling.

15. The most common styles of referencing.

A comparative analysis of the results of input and output diagnostics is presented in Table 3.

Table 3

Comparative analysis of the results of input and output $R P C Q$ diagnostics

\begin{tabular}{|c|c|c|c|c|}
\hline ASR & Resp. No & Input diagnostics, \% & Output diagnostics, $\%$ & $\begin{array}{c}\text { RPCQ } \\
\text { Progress, \% }\end{array}$ \\
\hline \multirow{2}{*}{ 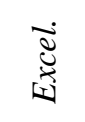 } & 1 & $79.2 \%$ & $88.9 \%$ & $9.7 \%$ \\
\hline & 2 & $82.5 \%$ & $87.8 \%$ & $5.3 \%$ \\
\hline \multirow{4}{*}{$\begin{array}{l}3 \\
8 \\
\infty \\
2 \\
2 \\
0\end{array}$} & 3 & $52.3 \%$ & $68.9 \%$ & $16.6 \%$ \\
\hline & 4 & $49.7 \%$ & $60.0 \%$ & $10.3 \%$ \\
\hline & 5 & $64.7 \%$ & $72.3 \%$ & $7.6 \%$ \\
\hline & 6 & $78.4 \%$ & $86.5 \%$ & $8.1 \%$ \\
\hline \multirow{6}{*}{$\begin{array}{l}3 \\
8 \\
0\end{array}$} & 7 & $44.2 \%$ & $56.7 \%$ & $12.5 \%$ \\
\hline & 8 & $56.8 \%$ & $70.1 \%$ & $13.3 \%$ \\
\hline & 9 & $51.3 \%$ & $66.5 \%$ & $15.2 \%$ \\
\hline & 10 & $62.9 \%$ & $70.7 \%$ & $7.8 \%$ \\
\hline & 11 & $70.3 \%$ & $80.9 \%$ & $10.6 \%$ \\
\hline & 12 & $65.6 \%$ & $70.8 \%$ & $5.2 \%$ \\
\hline \multirow{3}{*}{. } & 13 & $42.7 \%$ & $49.9 \%$ & $7.2 \%$ \\
\hline & 14 & $43.8 \%$ & $50.5 \%$ & $6.7 \%$ \\
\hline & 15 & $41.0 \%$ & $44.3 \%$ & $3.3 \%$ \\
\hline \multirow{2}{*}{$\underset{5}{\stackrel{5}{5}}$} & 16 & $39.9 \%$ & $48.6 \%$ & $8.7 \%$ \\
\hline & 17 & $36.7 \%$ & $49.2 \%$ & $12.5 \%$ \\
\hline \multicolumn{2}{|c|}{ Averagely } & $56,6 \%$ & $66.0 \%$ & $9.4 \%$ \\
\hline
\end{tabular}

The table of results shows that the RPCQ level is positive in all respondents. The minimum growth rate of RPCQ was 3.3\%, and the maximum - 16.6\%. The difference between the upper and lower limits was $13.3 \%$. This indicates a significant heterogeneity of results, the 
explanation of which may be the subject of a separate study. We can see that even within one subgroup, the level of academic success shows significant fluctuations in RPCQ improvement rates (up to $4.4 \%$ — in the range of excellent academic success rate; up to $9.0 \%$ — in the range of very good; up to $10.0 \%$ - in the range of good; up to $3.9 \%$ - in the range of satisfactory; up to $3.8 \%$ - in the range of a sufficient academic success rate). This indicates the factors other than the academic success rate that affect the level of RPCQ progress. The study of these factors may be the subject of further research in line with the application of research proposal not as a reporting and control form, but as a special teaching method. The distribution of respondents by levels of progress is given in Table 4.

\section{Table 4}

Distribution of respondents by levels of RPCQ progress

\begin{tabular}{lcc}
\hline RPCQ Progress Level & Number of respondents & $\begin{array}{c}\text { \% Fom general number of } \\
\text { respondents }\end{array}$ \\
\hline $1-5 \%$ - low progress & 3 & $17.7 \%$ \\
$6-10 \%-$ satisfactory & 9 & $52.9 \%$ \\
$11-15 \%$ - good & 4 & $23.5 \%$ \\
$16-20 \%-$ very good & 1 & $5.9 \%$ \\
$\geq 21-$ advanced & 0 & $0.0 \%$ \\
\hline
\end{tabular}

The results are visualized in Figure 1.

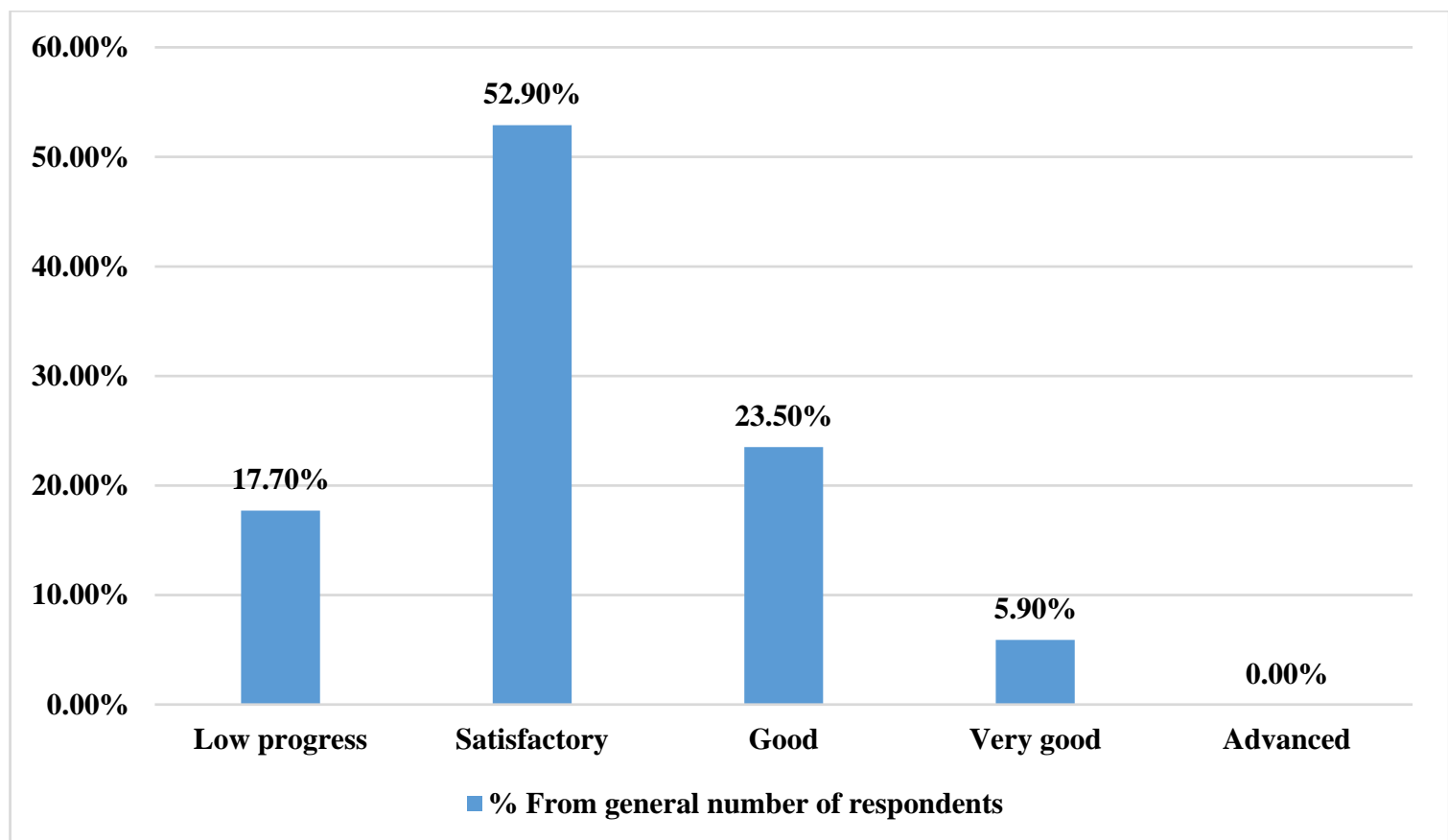

Figure 1. Percentage distribution of respondents by levels of RPCQ progress 
So, in $52.9 \%$ of cases, the progress of RPCQ focused on Satisfactory Level. At the same time, the Advanced level of RPCQ progress is not represented at all.

\section{Discussion}

Research proposal is a type of academic writing and at the same time one of the most important search skills of students of HEIs, which is related to some other types of research activities, such as written assignments, academic reports, term examination and graduation theses (Kheryadi, 2018; Naude \& Naude, 2017). However, the research proposal is a generalised kind of academic writing in relation to the others listed. On the one hand, this means that teaching the specifics of preparing students for academic writing and training students' skills of presentation of written assignments, academic reports, term examination and graduation theses will be beneficial for writing a research proposal (in terms of the points where these types of work intersect). On the other hand, researchers of a wide range of problems of research proposal applications and the experience of our empirical research clearly show that writing a research proposal in comparison with other types of academic writing and academic reporting in general has its distinctive features (Kheryadi, 2018; Suryatiningsih, 2019).

This necessitates a special preparation of students to write a research proposal. Moreover, this is in line with the tendencies of higher education to strengthen the research component, the development of students' specific research competence in order to build a knowledge-based society. If the research proposal is used not as a special form of reporting during admission to master's and postgraduate studies, but as a specific type of organisation of in-class and extracurricular educational activities of students, the research proposal becomes an innovative teaching method. The tasks of modern higher education are multi-purpose:

(1) preparation of students in the field of active citizenship for activities within the knowledge-based society;

(2) providing students with a set of competencies in the paradigm of the employability concept;

(3) supporting the personal development of students;

(4) laying a solid foundation of knowledge and stimulating research and innovation (ESG, 2015).

All of them are implemented in the process of applying the research proposal method, which was reported by respondents and teachers during the general conference meeting. Samaya and Suryadi (2019) generally actualise the problem of written assignments in university studies: they say that written assignment should be conceptualised with the goals that are 
predicted to be achieved in the learning process. In our research, such a deep perspective conceptualisation is the development of research competence. To overcome the difficulties of writing a research proposal, it is recommended to use a mind mapping technique based on the principles of brain management, which can be effective in unlocking all of the hidden potencies and capacity of the brain (Samaya \& Suryadi, 2019). The first stages of writing a research proposal are the most difficult, choosing the object, subject of study and formulation of a relevant topic that would be relevant to modern linguistics or literature is especially difficult for students (Pringle-Barnes \& Cheng, 2018; Al Qunayeer, 2020).

In the process of teaching students, the specifics of academic writing, in particular writing research proposal, it is necessary to more carefully train the skills of composing the paragraph of the background of the study. There is also a need to require students to read relevant references to support the quotations: for the scientific world, the whole process of research on a topic is a kind of metatext, various aspects of which are created by a number of researchers from around the world working on a given topic. In this context, it is also important to develop the ability to find a gap in the previous research (Suryatiningsih, 2019). In general, the motivation of students to carry out scientific activities requires additional didactic work.

Two types of experience become apparent in the process of applying a research proposal: one — when students solve problems related to writing a research proposal independently or with minimal intervention of the supervisor. Another experience is when difficulties at the very beginning of work become an insurmountable obstacle to progress (Pringle-Barnes \& Cheng, 2018; Wa Mungai, 2019; Morris, 2020). In our opinion, the reason is the lack of communicative and motivational support, as well as the shortcomings of academic advising style, which is especially relevant in the format of distance learning for the students who write their research proposals during this period. However, it is not limited by the shortcomings of academic advising style, as the analysis of the communicative support of respondents assigned to them by academic advisors showed a significant inconsistency on this issue. In some cases, the correct, partnership-collaborative method of intensive scientificconsultative support resulted in unexpectedly low results of RPCQ progress and, in general, low quality of prepared research proposals.

Additional insights into understanding the specifics of the application of the research proposal method are given by the fact that the Advanced level of RPCQ progress is not presented at all. On the one hand, this may indicate the need for more time for higher progress. On the other hand, it may indicate a lack of practical or theoretical and instructional aspects of learning, or in general such nature of research competence, which is difficult to target 
stimulation and training. Despite the advantages of the research proposal method for teaching students' methods of working with research, it should not be limited to the development of research competence in students. In particular, it would be effective to synergise the research proposal with the method of critique/critical report, brief outlines, essays, presentations, etc. (Edberg, 2018; Saeed et al., 2020).

Finally, the main limitations associated with the application of the proposed methodology are related to the small number of students involved in the study. That is, with the increase in the number of respondents, the final result may fluctuate slightly, especially in relation to the final ratings by the number of points scored. However, the effectiveness of the research proposal method remains unquestionable and enables the realization of students' research competencies, improves their soft and hard skills. That is, it is a universal method of organizing educational activities in higher education. It also requires hard work on the part of both the teacher and the students. In addition, additional work is needed to control the student's independent work, individual learning and increase motivation.

\section{Conclusions}

This study is based on the principled position on the need to integrate elements of research in the learning environment for not only of those students who plan to continue their graduate and postgraduate studies, but also at the stage of obtaining a bachelor's degree in general. It is the application of the research proposal as a method of organising students' educational activities that will allow attracting more students to study at further levels of the educational vertical. The research proposal has the potential to attract students to research, to show the way and to explain the procedure of scientific research in accordance with the field of specialisation. Such trainings can become a preparatory stage for master's and postgraduate studies and lay the foundations for the development of research competence.

On the other hand, since, for example, postgraduate studies necessarily require thorough research, preparation for its implementation and teaching students the principles of working with varieties of academic writing should begin as early as possible: both to develop research skills and to identify ability and arouse students' interest in research. This will further stimulate a creative pedagogical search in the process of teaching professional activity. Among other things, attention to topical issues of philological science will also stimulate students to discover scientific abilities in their students. Besides, teaching in HEIs (in case of continuing studies at the university), which is mostly associated with a master's degree or $\mathrm{PhD}$, is inseparable from accountable and supervised research in accordance with modern requirements. 


\section{References}

Al Qunayeer, H. S. (2020). supporting postgraduates in research proposals through peer feedback in a Malaysian University. Journal of Further and Higher Education, 44 (7), 115. https://doi.org/10.1080/0309877X.2019.1627299

Augustsson, G., \& Jaldemark, J. (2014). Online supervision: A theory of supervisors' strategic communicative influence on student dissertations. Higher Education, 67 (1), 19-33. https://doi.org/10.1007/s10734-013-9638-4

Del Río, G. N. B. (2021). A useful framework for teacher professional development for online and blended learning to use as guidance in times of crisis. Educational Technology Research and Development, 69 (1), 7-9. https://doi.org/10.1007/s11423-021-09953-y

Djoub, Z. (2017). Enhancing students' critical thinking through portfolios: Portfolio content and process of use. In Handbook of Research on Creative Problem-Solving Skill Development in Higher Education (pp. 235-259). Hershey: IGI Global.

Duignan, B. (2021). The origins of modern aesthetics. https://www.britannica.com/topic/artfor-arts-sake

Edberg, H. (2018). Creative writing for critical thinking. Stockholm: Palgrave Macmillan.

ESG. (2015). Standards and Guidelines for Quality Assurance in the European Higher Education Area (ESG). https://www.britishcouncil.org.ua/sites/default/files/standardsand-guidelines_for_qa_in_the_ehea_2015.pdf

Grbić, M., Jakšić, M., \& Todorović, V. (2020). Higher education financial sources and models: A comparative analysis in selected EU countries. In Handbook of Research on Enhancing Innovation in Higher Education Institutions (pp. 317-340). Hershey: IGI Global.

Jansen, D. (2020). What (exactly) is a research proposal? https://gradcoach.com/what-is-aresearch-proposal-dissertation-thesis/

Kheryadi, K. (2018). The student's ability and problems in writing introduction of research proposal. EEAL Journal (English Education and Applied Linguistics Journal), 1 (1). https://doi.org/10.31980/eeal

Koval, V., \& Masliuk, K. (2018). The practical training of students-philologists in the process of professional competence forming. Philological journal, 1, 152-162.

Maznun, M. D. B., Monsefi, R., \& Nimehchisalem, V. (2017). Undergraduate ESL students' difficulties in writing the introduction for research reports. Advances in Language and Literary Studies, 8 (1), 9-16. https://doi.org/10.7575/AIAC.ALLS.V.8N.1P.9 
Medina, L. C. (2018). Blended learning: Deficits and prospects in higher education. Australasian Journal of Educational Technology, $34 \quad$ (1), 42-56. https://doi.org/10.14742/ajet.3100

Ministry of Education and Science of Ukraine. (2019). Order №869 "On approval of the standard of higher education in the specialty 035 "Philology" for the first (bachelor's) level of higher education”. https://mon.gov.ua/storage/app/media/vishchaosvita/zatverdzeni\%20standarty/2019/06/ 25/035-filologiya-bakalavr.pdf

Morris, K. (2020). Writing a research proposal workshop. http://insight.cumbria.ac.uk/id/eprint/5978/1/Morris_5th\%20November\%20research\%2 0event.pdf

Naudé, J. A., \& Miller-Naudé, C. L. (2017). Linguistics and philology-separate, overlapping or subordinate/superordinate disciplines? https://www.researchgate.net/profile/JacobusNaude/publication/322644211_The_Discip linarity_of_Linguistics_and_Philology/links/5a663fed4585158bca544d55/TheDisciplinarity-of-Linguistics-and-Philology.pdf

O’Hara, R. J. (1996). Trees of history in systematics and philology. Memorie della Società Italiana di Scienze Naturali e del Museo Civico di Storia Naturale di Milano, 27 (1), 8188 .

Opaleye, K., \& Aiyedun, E. (2020). Theoretical structure of a research proposal. Oguya International Journal of Contemporary Issues (OIJCI), 1(1), 187-192.

Pardede, P. (2019). ELT research proposal writing guidelines. http://repository.uki.ac.id/905/1/ELT\%20Research\%20Proposal\%20Writing\%20Guideli nes.pdf

Pollock, S. (2009). Future philology? The fate of a soft science in a hard world. Critical Inquiry, 35 (4), 931-961. https://doi.org/10.1086/599594

Pringle Barnes, P. G., \& Cheng, M. (2018). Working independently on the dissertation proposal: Experiences of international master's students. Journal of Further and Higher Education, 43 (8), 1120-1132. https://doi.org/10.1080/0309877X.2018.1450965

Rahman, H. (2009). Network deployment for social benefits in developing countries. In Encyclopedia of Multimedia Technology and Networking, Second Edition (pp. 10481054). Hershey: IGI Global.

Roman, T. A., \& Uttamchandani, S. (2018). Researching pedagogy within small active learning classrooms: Examining enacted pedagogies of learner and instructor interactions. 
International Journal of Research \& Method in Education, 41 (1), 1-21. https://doi.org/10.1080/1743727x.2018.1452199

Saeed, M. A., Al-Ahdal, M. H., \& Al Qunayeer, H. S. (2020). Integrating research proposal writing into a postgraduate research method course: what does it tell us? International Journal of Research \& Method in Education, 44 (3), 303-318.

Samaya, D., \& Suryadi, E. (2019). Improving writing skill of research proposal through mind mapping of economics faculty students of Tridinanti, University Palembang, advances in social science, education and humanities research. In International Conference on Progressive Education. https://www.atlantis-press.com/article/125937604.pdf

Suryatiningsih, N. (2019). EFL students' difficulties in writing a research proposal. International Journal of Humanities and Innovation (IJHI), 2 (4), 96-102. https://doi.org/10.33750/ijhi.v2i4.49

Verkhovna Rada of Ukraine. (2017). On Education № 2145-VIII. https://zakon.rada.gov.ua/laws/show/2145-19\#Text

Verkhovna Rada of Ukraine. (2014). On Higher Education 1556-VI. https://zakon.rada.gov.ua/laws/show/1556-18\#Text

Verkhovna Rada of Ukraine. (2016). On Scientific and Scientific-Technical Activity 848-VIII. https://zakon.rada.gov.ua/laws/show/848-19?lang=en\#Text

Wa Mungai, N. (2019). Designing a PhD proposal in mixed method research. In Social research methodology and new techniques in analysis, interpretation, and writing (pp. 36-48). IGI Global. https://doi.org/10.4018/978-1-5225-7897-0.ch003

Yusuf, M. (2013). Students' problems in writing research proposal: A case study of the fifth semester students of English education department, State Institute for Islamic Studies Sunan Ampel Surabaya. http://humanistudies.com/ijhi/article/view/49/48

Zondi, W. B. (2018). A guide to writing a sound research proposal. Opción: Revista de Ciencias Humanas y Sociales, 14, 497-519. 
Appendix A

\section{Typical Preliminary Research Proposal}

Title Page: (Write this in accordance with the specification provided by the university or organization to which the proposal is addressed).

\section{TITLE}

\section{A. Introduction}

1. Identify the general topic in the first sentence.

2. In the second sentence, provide the background to the research problem.

3. Next, state the research aim and the research problem and justify why it needs to study.

\section{B. Literature Review}

In one or two paragraph, the major schools of thought on the topic and very briefly review the relevant current studies main findings reported on the chosen topic. End this section by restating the research question to show how it fits into this larger picture.

\section{Conceptual Framework}

This section, sometimes called the Proposed Theoretical Model) links the findings in the literature with the writer's ideas to show the expected contribution of the research to the topic under study, state the hypotheses to be tested).

\section{Method}

Describes the research design (quantitative, qualitative, or mixed methods), population and sample, instruments, and data analysis technique.

\section{E. Expected Outcomes}

Outlines the expected results, how they will be interpreted, and how they will enrich the present knowledge (i.e. literature) concerning the topic.

\section{Timeline and Budget}

\section{References}

Lists all sources cited in the proposal.

Source: Pardede (2019) 


\section{Typical Standard Research Proposal}

Title Page: (Write this in accordance with the specification provided by the university or organization to which the proposal is addressed).

Chapter I: Introduction

A. Background

B. Statement of topic area

C. Statement of research problem and justification for studying it

D. Research Objectives

E. Research Significances

F. Research Scope

G. Operational definitions

\section{Chapter II: Literature review}

A. Summary and synthesis of the major schools of thought s on the topic and a review of the relevant current main findings reported on the chosen topic.

B. Conceptual framework (links the research variables which has been specified based on the findings in the literature so that the research questions and hypothesis could be explicitly stated in the next subsection. It also shows how the present proposed research could provide solutions to the problems so that the expected contribution to the topic under study (research significances) can be stated.

C. Specific research question(s) and hypothesis to be tested.

\section{Chapter III: Method}

A. Research design

B. Participants

1. Who? How many?

2. Characteristics (male/female, proficiency level, native language, etc.)

3. Sampling Technique

C. Materials

1. What equipment? What Setting?

2. What data collecting instruments?

D. Procedures

1. How is the treatment to be administered?

2 . How/when is the testing to be conducted?

3. What analysis techniques to be employed?

Timeline and Budget

\section{References}

Source: Pardede (2019) 
Appendix B

\section{Anonymous questionnaire for detecting student's confidence in research proposal writing}

Rate on a scale of 1-5 the level of your confidence or competence in the following positions.

1. You are regularly engaged in scientific activities.

2. You have some sphere of scientific interest.

3. You are well versed in the current issues of modern linguistic and literary studies.

4. You have your own (or co-authored) scientific publications.

5. You plan to connect your activity with the scientific sphere.

6. Skill in writing research types of works.

7. You are well acquainted with the specifics of proposal writing.

8. You get regular and deliberate support from your lecturers in the question of involvement to scientific work.

9. You are active learner.

Estimate your skill in:

1....choosing the research area and detecting the research problem.

2....formulating the title of the research proposal.

3. ...abstract writing.

4. ...research context involving.

$5 . .$. search of relevant references.

6. ...literature review conducting.

7. ...research questions developing.

8. ...research methods selecting.

9. ...extracting the significance of research.

$10 . . .$. references arrangement.

11. ...deadline compliance. 
Appendix C

\section{Professional inclinations questionnaire \\ (By l. Yovaysha's technique modified by H. V. Rezapkina)}

\section{Test purpose}

Diagnostics of the professional inclinations of the respondents.

\section{Test instructions}

In order to determine your professional inclinations, choose one of three options — "a", "b" or "c" — and mark it on the form.

\section{Test material}

1. In my professional activity I would like to:

1. Communicate with a wide variety of people;

2. Make films, write books, paint, perform on stage, etc.

3. Engage in calculations; maintain documentation.

2. In a book or movie, I am most attracted to:

1. The ability to follow the author's train of thought;

2. Art form, skill of a writer or director;

3. Plot, actions of heroes.

3. I will be more pleased with the Nobel Prize

1. For social activities;

2. In the field of science;

3. In the field of art.

4. I would rather agree to become:

1. Chief mechanician;

2. Head of the expedition;

3. Chief accountant. 
5. The future of people is determined by:

1. Mutual understanding between people;

2. Scientific discoveries;

3. Development of production.

6. If I become a leader, first of all I will deal with:

1. Creation of a friendly, cohesive team;

2. Development of new teaching technologies;

3. Work with documents.

7. At a technical exhibition I will be more attracted to:

1.Internal arrangement of exhibits;

2. Their practical application;

3. Appearance of the exhibits (colour, shapes);

8. In people I value above all:

1. Friendliness and responsiveness;

2. Courage and endurance;

3. Commitment and accuracy.

9. In my free time, I would like to:

1. Set up various experiments;

2. Write poetry, compose music or paint;

3. Exercise.

10. When traveling abroad, I will be more likely interested in:

1. The opportunity to learn about the history and culture of another country;

2. Extreme tourism (mountaineering, windsurfing, mountain skiing);

3. Business communication;

11. I'm more interested in talking about:

1. Human relationships;

2. A new scientific hypothesis; 
3. Technical characteristics of the new model of the car, computer.

12. If there were only three circles in my school, I would choose:

1. Technical;

2. Musical;

3. Sports.

13. The school should pay particular attention to:

1. Improving mutual understanding between teachers and students;

2. Maintaining the health of students, playing sports;

3. Strengthening discipline.

14. I watch with great pleasure:

1. Popular science films;

2. Programmes about culture and art;

3. Sports programmes.

15. I would like to work:

1. With children or peers;

2. With machines, mechanisms;

3. With objects of nature.

16. The school must first of all:

1. Teach communication with other people;

2. Give knowledge;

3. Teach work skills.

17. The main thing in life:

1. Have the opportunity to be creative;

2. Lead a healthy lifestyle;

3. Plan your affairs carefully.

18. The state should first of all take care of:

1. Protection of the interests and rights of citizens; 
2. Advances in science and technology;

3. Material well-being of citizens.

19. I like the lessons the most:

1. Labour;

2. Physical education;

3. Mathematics.

20. It would be more interesting for me to:

1. Be engaged in the sale of goods;

2. Make products;

3. Plan the production of goods.

21. I prefer to read articles about:

1. Outstanding scientists and their discoveries;

2. Interesting inventions;

3. Life and work of writers, artists, musicians.

22. In my free time I like:

1. Reading, thinking, reasoning;

2. Tinkering, sewing, caring for animals, plants;

3. Going to exhibitions, concerts, museums.

23. Of greater interest to me will be the message about:

1. Scientific discovery;

2. Art exhibition;

3. Economic situation.

24. I prefer to work in:

1. A room where there are many people;

2. Unusual conditions;

3. A regular office 


\section{Key to the text}

\begin{tabular}{|c|c|c|c|c|c|c|c|c|c|c|c|c|c|}
\hline $\mathrm{N}$ & $\mathrm{I}$ & II & III & IV & V & VI & N & I & II & III & IV & V & VI \\
\hline 1 & $\mathrm{a}$ & & & $\mathrm{b}$ & & $\mathrm{c}$ & 13 & $\mathrm{a}$ & & & & $\mathrm{b}$ & $\mathrm{c}$ \\
\hline 2 & & $\mathrm{a}$ & & $\mathrm{b}$ & $\mathrm{c}$ & & 14 & & $\mathrm{a}$ & & $\mathrm{b}$ & $\mathrm{c}$ & \\
\hline 3 & $\mathrm{a}$ & $\mathrm{b}$ & & $\mathrm{c}$ & & & 15 & $\mathrm{a}$ & & $\mathrm{b}$ & & $\mathrm{c}$ & \\
\hline 4 & & & $\mathrm{a}$ & & $\mathrm{b}$ & $\mathrm{c}$ & 16 & $\mathrm{a}$ & & $\mathrm{b}$ & & & $\mathrm{c}$ \\
\hline 5 & $\mathrm{a}$ & $\mathrm{b}$ & $\mathrm{c}$ & & & & 17 & & & & $\mathrm{a}$ & $\mathrm{b}$ & $\mathrm{c}$ \\
\hline 6 & $\mathrm{a}$ & $\mathrm{b}$ & & & & $\mathrm{c}$ & 18 & $\mathrm{a}$ & $\mathrm{b}$ & $\mathrm{c}$ & & & \\
\hline 7 & & $\mathrm{a}$ & $\mathrm{b}$ & $\mathrm{c}$ & & & 19 & & & $\mathrm{a}$ & & $\mathrm{b}$ & $\mathrm{c}$ \\
\hline 8 & $\mathrm{a}$ & & & & $\mathrm{b}$ & $\mathrm{c}$ & 20 & $\mathrm{a}$ & & $\mathrm{b}$ & & & $\mathrm{c}$ \\
\hline 9 & & $\mathrm{a}$ & & $\mathrm{b}$ & $\mathrm{c}$ & & 21 & & $\mathrm{a}$ & $\mathrm{b}$ & $\mathrm{c}$ & & \\
\hline 10 & & & & $\mathrm{a}$ & $\mathrm{b}$ & $\mathrm{c}$ & 22 & & $\mathrm{a}$ & $\mathrm{b}$ & $\mathrm{c}$ & & \\
\hline 11 & $\mathrm{a}$ & $\mathrm{b}$ & $\mathrm{c}$ & & & & 23 & & $\mathrm{a}$ & & $\mathrm{b}$ & & $\mathrm{c}$ \\
\hline 12 & & & $\mathrm{a}$ & $\mathrm{b}$ & $\mathrm{c}$ & & 24 & $\mathrm{a}$ & & & & $\mathrm{b}$ & $\mathrm{c}$ \\
\hline
\end{tabular}

\section{Processing test results}

Count the number of letters circled in each of the six columns, and write these six numbers in the blank boxes on the bottom line.

10-12 points - a pronounced professional inclination.

7-9 points - an inclination to a certain type of activity.

4-6 points - a weakly expressed professional inclination.

0-3 points - the professional inclination is not pronounced.

Six columns are six types of activities. Pay attention to those activities that scored the most points. Does your choice of profession coincide with the results obtained?

\section{Interpretation of the test results}

I. Inclination for work with people. Professions related to management, training, education, service (household, medical, reference and information). People who are successful in the professions of this group are distinguished by sociability, the ability to find a common language with different people, to understand their mood and intentions.

II. Inclination for research (intellectual) work. Professions related to scientific activities. In addition to special knowledge, such people are usually distinguished by rationality, independence of judgment, and an analytical mindset.

III. Inclination for practical activity. The range of these professions is very wide: production and processing of metal; assembly, installation of devices and mechanisms; repair, adjustment, 
maintenance of electronic and mechanical equipment; installation, repair of buildings, structures; transport management; manufacture of products.

IV. Inclination for aesthetic activities. Professions of a creative nature associated with visual, musical, literary and artistic, acting and stage activities. People of creative professions, in addition to special abilities (musical, literary, acting), are distinguished by originality and independence.

V. Inclination extreme activities. Professions related to sports, travel, expeditionary work, security and operational investigation, military service. All of them have special requirements for physical fitness, health, volitional qualities.

VI. Inclination for planned economic activities. Professions related to calculations and planning (accountant, economist); office work, analysis of texts and their transformation (editor, translator, linguist); a schematic representation of objects (draftsman, topographer). These professions require a person to be self-disciplined and accurate.

Author: Rezapkina H., Moscow, Russia, psychologist, profession consultant 